\title{
Parameters of adaptability, biological and economical valuable traits of soft wheat promising lines
}

\author{
T.Z. Moskalets ${ }^{1}$, A.H. Vovkohon ${ }^{2}$, O.B. Ovezmyradova ${ }^{3}$, H.V. Merzlova ${ }^{2}$, \\ O.M. Nevmerzhitska ${ }^{3}$, N.M. Plotnytska ${ }^{3}$, O.V. Gurmanchuk ${ }^{3}$, V.A. Nasikovskyi ${ }^{4}$, \\ O.O. Kravets ${ }^{5}$, V.V. Moskalets ${ }^{1}$ \\ ${ }^{1}$ Institute of Horticulture, National Academy of Agrarian Science of Ukraine \\ ${ }^{2}$ Bila Tserkva National Agrarian University, Ukraine \\ ${ }^{3}$ Polissia national university, Ukraine \\ ${ }^{4}$ National Universityof Life and Environmental Sciences of Ukraine \\ ${ }^{5}$ Vinnytsia Mykhailo Kotsiubynskyi State Pedagogical University, Ukraine \\ *Corresponding author E-mail: shunyascience@ukr.net
}

\section{Received: 09.09.2020. Accepted 20.10.2020}

\begin{abstract}
Results of research of soft winter wheat new lines of hexaploid level by morphological features, biological properties and biochemical parameters were given. During 2018-2020 in the Northern part of the Central Forest-Steppe of Ukraine the assessment of the general adaptive capacity by the yielding capacity and biological-agronomic traits are given and promising ones are highlighted (Donzorna, Flonormyra, Polezoriana). The new wheat lines have proved themselves well given the consistently high winter, drought resistance, and productivity, coefficient of variation is low, variance of stability, homeostaticity, and selection value high. According to the biochemical composition of the grain, the studied lines are characterized by medium and high 'raw' protein content and gluten content. New selection wheat lines own by the technological indicators (the volumetric bread outut of $100 \mathrm{~g}$ of drough, the total baking rating), flour 'quite satisfactory', 'good', and 'excellent' score (Sviatdonivka, Flonormyra). The new wheat line Donzorna is characterized by the presence of $1 \mathrm{BL} / 1 \mathrm{RS}$ wheat-rye translocation, which distinguishes it as a donor of resistance to biotic and abiotic factors and requires further more detailed study.
\end{abstract}

Keywords: Triticum aestivum L.; parameters of ecological plasticity and stability; 1BL/1RS wheat-rye translocation; Puccinia recondita f. sp. tritici Rob. ex Desm; yielding capacity; baking and technological properties of flour

\section{Introduction}

In the world wheat along with rice are the main food crops, and in many countries of the planet are the leading means of subsistence. The source of increasing grain production, in particular wheat, is the creation and implementation of new highperformance, plastic, with a high level of homeostasis of varieties, resistant to major pathogens, valuable in terms of baking quality (Weng et al., 2007; Li et al., 2020). The issue of improving the quality of wheat grain is one of the global problems of today (Tahmasebi et al., 2015; Toporash et al., 2017). This is especially true for Ukraine, it declares itself on the world market the everincreasing volume of grain exported. Unfortunately, Ukrainian wheat in general is inferior in grain quality to the best world varieties and often does not fully satisfy the national market the level of quality of wheat flour (Rybalka, 2011; Szakács et al., 2020) in the selection of soft winter wheat homogeneous genetic material, besides progress in increasing productivity varieties, caused a narrowing of their genetic basis and an increasing the affinity of the gene pool (Ivanova et al., 2019).

This led to that the vast majority of domestic varieties have a narrow technological direction of using (Rybalka, 2011; Kozub et al., 2018; Motsny, et al., 2017). In addition, the creation of new source breeding material with valuable economic features significantly limited by the lack of their environmental and molecular genetic characteristics, which is important in further selection. Because of that, the purpose and objectives of our research became a comprehensive study of the new gene plasma of soft wheat ( Triticum aestivum L.) winter type of growth for the conditions of the Forest-Steppe of Ukraine by productive, ecological adaptive potential and quality indicators.

\section{Materials and Methods}

During 2007-2017 at the Nosivska Breeding and Research Station of the NAAS selection work was started and in Bila Tserkva National Agrarian University work was continued with create a new gene plasma of soft wheat Polissia-Forest-Steppe subecotype. During 2018-2020 in the Central Forest-Steppe (V.M. Remeslo Myronivka Institute of Wheat NAAS), Eastern Forest-Steppe (Poltava State Agrarian Academy) and Northern Forest-Steppe (NSC 'Institute of Agriculture NAAS') ecological testing of the new wheat lines were conducted.

Mineral fertilizers and pesticides didn't use. The source material was varieties of different ecological and geographical provenance national and foreign selection of wheat: Maris yuntsman (GBR), Myronivska 61 (UA), Donska napivkarlykova (RUS), Myronivska 808 (UA), Kyianka (UA), Dobirna (UA), Kyshynivska intensyvna (MDA), Podolianka (UA), Poliska 92 (UA), Smuhlianka (UA), Yermak (RUS), Zoriana Nosivska (UA), Yuvivata 60 (UA), Prydesnianska napivkarlykova (UA), Norman (GBR), Florida (DEU). Hybridization was performed by the method manual castration of maternal components and pollination 'TVEL-method' 2-3 days after castration. 
All observations and assessments were performed according to the international CMEA classifier, methodological guidelines All-Union Institute of Plant Breeding and method of State variety testing (Tkachyk, 2016a).

Evaluation of the lines was performed on crops of competitive testing by such parameters as: productivity, resistance to pathogens and lying down plants, using the method of state testing (Tkachyk, 2016a). Morphological parameters of plants (leaf, bush, spike, grain) and stages of ontogeny were determined by Avdeev (2015), biometric parameters of the structure elements of the plants (height of plants, length of the main spike, number of the spikelets and of the grains in the main spike, the mass of grain from it, mass of 1000 grains) by Maysuryan, phenological phases of development by Takhtadzhn, Kuperman, duration of the growing season - by Kumakov, resistance to lying down plants, winter and drought resistance by Methods of examination of Plant Varieties of Cereals, Grains and LegumesTesting for Sutability to Dissemination in Ukraine (Tkachyk, 2016b). The degree of damage by the causative agent of brown leaf rust was determined by the Cobbs scale (Peterson et al., 1948), the actual area of leaf damage - on a scale CYMMUT (Roelfs et al., 1992) and point scale (Tkachyk, 2016a).

The accounting area of the experiment variant was $10 \mathrm{~m}^{2}$, experiments were laid down in a fourfold repetition. The results of the researches were processed statistically: arithmetic mean $(\dot{X})$, minimal $\left(X_{\min }\right)$, maximum value $\left(X_{\max }\right)$, range of variation $\left(R=X_{\max }-\right.$ $\left.\mathrm{X}_{\mathrm{min}}\right)$; coefficient of variation $(\mathrm{CV})$, stability variance $\left(\mathrm{Si}^{2}\right)$ have been defined. The plant resistance was determined to adverse environmental factors by homeostaticity $\left(\mathrm{H}_{\mathrm{om}}\right)$ (Khangildin \& Litvinenko, 1981; Eberhart \& Russel, 1966). The index of selection value was calculated by the formula: $\mathrm{Sc}=\dot{\mathrm{X}} \times \mathrm{X}_{\mathrm{lim}} / \mathrm{X}_{\mathrm{opt}}$, having accepted $\mathrm{X}_{\mathrm{lim}}$ - as the lowest value of the trait in the years of research $\left(\mathrm{X}_{\min }\right), \mathrm{X}_{\mathrm{opt}}$ - as the highest $\left(\mathrm{X}_{\max }\right)$.

Mathematical and statistical data processing was performed (Pakudin, 1973) using computer programs Statistica-5.5 та Excel-2003. The differences between the researches variants notions in the control and experimental groups were established using the ANOVA, where the differences were considered significant under $\mathrm{P}<0.05$. The average notion of the standard error $(x \pm S E)$ was determined.

Climate and weather Forest-Steppe conditions are characterized by moderate continentality. The average air temperature makes $6.9^{\circ} \mathrm{C}$ with significant fluctuations by months and average annual rainfall of $529 \mathrm{~mm}$, which during the growing season unevenly distributed: in the summer them are much more than in the spring and the autumn. The conventional technology for the region grain crops winter crops used in the studies. Soil - black humus earth general, deep, medium humic and clay-loam soil, with humus content - 3.5\% low-duty hydrolizable nitrogen (by Kornfild) - 140 mobile phosphorus and exchangeable potassium (by Chirikov) respectively 120 and $90 \mathrm{mg} / \mathrm{kg}$ soil. The sowing was carried out in the optimal for zone dates: 20-30 September, string method of seeding norm of similar 5.0 million seeds/ha.

Years of researches have varied by hydrothermal regime: 2011-2013, 2015-2019 marked deficits rainfall and increased temperatures above average long-term norms in phase outlet pipes and phase of formation spike compared with favorable enough wet spring period (2019), which gave opportunity to comprehensively evaluate the adaptability the studied genotypes plant to climate in Forest-Steppe and Polissia-Forest-Steppe ecotopes and the ability to realize theirs biological potential.

The vegetation periods 2018-2019 were arid by the coefficient of variation materiality on precipitation (the coefficient of variation materiality $<1$ ); the coefficient of variation materiality of the temperature regime - close to the average long-term exponent $( \pm 0.2-$ 1.3). However, the coefficient of variation materiality for hydrothermal coefficient (index) (HTI) during the researches approached the value of the index in conditions close to extreme. The most extreme months of atypical weather conditions were in May 2018 ($5.2)$, July 2018- $2020(-2.25--4.17)$, that in all the years research May - the period of active plant growth and development characterized by the most extreme weather conditions, which significantly delayed accumulation intensity of the dry vegetative mass. Generalized analysis of of meteorological conditions suggests that deviation of a number of parameters, including temperature, an amount of precipitation with medium perennial away from the critical values, except for some months of plants growth in the years.

The identification of low-gliadin proteins were performed by electrophoresis polyacrylamide gel (Popierielia, 1989; Osterman, 2002) in the Plant Production Institute nd. a. V.Ya. Yuryev of NAAS of Ukraine and the Institute of Plant Protection, using the catalog and nomenclature Payne (Payne, Lawrence, 1983). The content of protein and gluten were determined by spectrometric analyzer 'Inframatic 8600', the total baking rating was carried out on a 9-point scale, given the volumetric yield of bread, surface, shape, colour of bread crust, its porosity, elasticity, pulp colour, taste and smell (Tkachyk, 2016b).

\section{Results and Discussion}

During 2015-2020, selection and environmental studies were conducted to obtain and selection a new source material for soft winter wheat of the hexaploid level. Comprehensive long-term studing of hybrids F3-F4, lines by morphological, biochemical parameters and molecular genetic markers made it possible to obtain promising genetic material, the most important of which are given below. Morphological and ontogenetic parameters of selected wheat lines are given in Table 1 according to the results of ecological testing.

Table 1. Characteristics of soft winter wheat varieties and lines by biological features and economically valuable features (average 2018-2020).

\begin{tabular}{|c|c|c|c|c|c|c|c|}
\hline Variety, line & DGS, days & $\begin{array}{c}\text { Plant } \\
\text { height, cm }\end{array}$ & $\begin{array}{c}\text { Ear length, } \\
\mathbf{c m}\end{array}$ & $\begin{array}{l}\text { The number } \\
\text { of seeds in } \\
\text { the main } \\
\text { spike, pcs. }\end{array}$ & $\begin{array}{c}\text { Grain mass } \\
\text { of the main } \\
\text { spike, } \mathbf{g}\end{array}$ & $\begin{array}{c}\text { Resis- } \\
\text { tance to } \\
\text { lying } \\
\text { down } \\
\text { plants, } \\
\text { points }\end{array}$ & $\begin{array}{c}\text { Mass of } \\
1000 \text { grains, } \\
\mathrm{g}\end{array}$ \\
\hline Smuhlianka & $284 \pm 2.3$ & $85.0 \pm 2.1$ & $8.1 \pm 0.2$ & $53 \pm 2.1$ & $2.1 \pm 0.1$ & 8 & $50.8 \pm 0.6$ \\
\hline Kyievopolka & $285 \pm 1.8$ & $86.5 \pm 1.5$ & $10.6 \pm 0.1^{*}$ & $59 \pm 1.2^{*}$ & $1.9 \pm 0.3$ & $9 *$ & $51.3 \pm 1.0$ \\
\hline Sviatdonivka & $287 \pm 2.0$ & $79.5 \pm 2.3^{*}$ & $9.5 \pm 0.0^{*}$ & $58 \pm 2.1^{*}$ & $2.7 \pm 0.2^{*}$ & $9 *$ & $52.5 \pm 0.8^{*}$ \\
\hline Donzorna & $279 \pm 1.5^{*}$ & $71.0 \pm 1.8^{*}$ & $10.2 \pm 0.3^{*}$ & $55 \pm 1.6$ & $2.9 \pm 0.1 *$ & $9 *$ & $52.0 \pm 0.7 *$ \\
\hline Polezoriana & $289 \pm 1.9 *$ & $90.2 \pm 1.3^{*}$ & $10.7 \pm 0.1^{*}$ & $53 \pm 0.8$ & $2.5 \pm 0.2^{*}$ & $9 *$ & $50.6 \pm 0.8$ \\
\hline Flonormyra & $290 \pm 1.8^{*}$ & $87.8 \pm 1.7$ & $9.2 \pm 0.2^{*}$ & $57 \pm 1.0^{*}$ & $2.8 \pm 0.3^{*}$ & 8 & $59.8 \pm 0.5^{*}$ \\
\hline
\end{tabular}

Note: * - significance P $<0.05$ as compared to the control (Smuhlianka variety); DGS - duration of the growing season. 
During 2018-2020, in the northern part of the Central Forest-Steppe of Ukraine, the highest average yield was observed in Flonormyra (7.1 t/ha) and Donzorna (6.7 t/ha) (Table 2). In 2019 the lowest performance features were characterized by most of the studied samples. Donzorna, Polezoriana lines exceeded control (Smuhlianka) on average over three years of research significantly $-0.6-2.2 \mathrm{t} / \mathrm{ha}$ at $\mathrm{p}<0.05$. Kyievopolka, Sviatdonivka, Flonormyra lines were at the level of control $-5.2-5.9 \mathrm{t} / \mathrm{ha}$.

Table 2. The yielding capacity of the soft winter wheat varieties and lines, 2018-2020.

\begin{tabular}{|c|c|c|c|c|c|c|c|c|}
\hline \multirow{2}{*}{ Variety, line } & \multicolumn{2}{|c|}{2018} & \multicolumn{2}{|c|}{2019} & \multicolumn{2}{|c|}{2020} & \multicolumn{2}{|c|}{ Average } \\
\hline & t/ha & \pm to $\mathrm{crl}$ & t/ha & \pm to crl & t/ha & \pm to $\mathrm{crl}$ & t/ha & \pm to $\mathrm{crl}$ \\
\hline Smuhlianka & $4.8 \pm 0.5$ & & $5.2 \pm 0.3$ & & $4.9 \pm 0.2$ & & $4.7 \pm 0.3$ & \\
\hline Kyievopolka & $5.5 \pm 0.4$ & 0.6 & $4.9 \pm 0.1$ & 0.2 & $5.4 \pm 0.5$ & 0.5 & $5.2 \pm 0.3$ & 0.5 \\
\hline Sviatdonivka & $6.0 \pm 0.5$ & 1.1 & $5.0 \pm 0.4$ & 0.1 & $5.9 \pm 0.3^{*}$ & 1.0 & $5.6 \pm 0.4^{*}$ & 0.9 \\
\hline Donzorna & $6.7 \pm 0.4 *$ & 1.8 & $5.8 \pm 0.2^{*}$ & 0.7 & $6.3 \pm 0.2^{*}$ & 1.4 & $6.3 \pm 0.2^{*}$ & 1.6 \\
\hline Polezoriana & $6.4 \pm 0.3^{*}$ & 1.5 & $5.9 \pm 0.1^{*}$ & 0.8 & $6.4 \pm 0.3^{*}$ & 1.5 & $6.2 \pm 0.2^{*}$ & 1.5 \\
\hline Flonormyra & $7.1 \pm 0.5^{*}$ & 2.2 & $5.0 \pm 0.2$ & 0.1 & $5.7 \pm 0.2^{*}$ & 0.8 & $5.9 \pm 0.2^{*}$ & 1.2 \\
\hline
\end{tabular}

Note: * significance P $<0.05$ as compared to the control (Smuhlianka variety); crl - control.

The features of adaptability and stability of productivity and yielding capacity have important meaning. Donzorna, Kyievopolka lines are the best in terms of stability of the range of variation $(R)$ of the yielding capacity. Donzorna, Kyievopolka, Polezoriana lines are better by the coefficient of variation, the variance of stability and homeostaticity (Table 3); Donzorna and Polezoriana stood out by the selection value.

Table 3. Characteristics of soft winter wheat varieties and lines by the parameters of productivity and stability (average 20182020).

\begin{tabular}{lcccccccc}
\hline \multicolumn{1}{c}{ Variety, line } & $\dot{\mathbf{x}}$ & $\mathbf{X}_{\max }$ & $\mathbf{X}_{\min }$ & $\mathbf{R}$ & $\mathbf{C V}, \mathbf{\%}$ & $\mathbf{S i}^{\mathbf{2}}$ & $\mathbf{H}_{\text {om }}$ & $\mathbf{S c}$ \\
Smuhlianka & 5.90 & 5.50 & 4.80 & 0.40 & 5.6 & 0.17 & 33.5 & 4.84 \\
Kyievopolka & 5.29 & 5.51 & 4.95 & 0.56 & 8.7 & 0.21 & 19.2 \\
Sviatdonivka & 5.66 & 6.04 & 5.02 & 1.20 & 14.5 & 0.67 & 10.6 \\
Donzorna & 6.31 & 6.76 & 5.80 & 0.96 & 11.3 & 0.51 & 13.1 & 5.70 \\
Polezoriana & 6.28 & 6.47 & 5.97 & 1.08 & 12.3 & 0.60 & 12.9 & 5.79 \\
Flonormyra & 5.96 & 7.12 & 5.04 & 2.08 & 16.4 & 0.97 & 6.8 & 4.52 \\
\hline
\end{tabular}

Note: control - Smuhlianka variety.

Kyievopolka line of the soft winter wheat was selected by Kyshynivska intensivna individual selection of the hybrid combination 9 Poliska $87 \times \sigma^{x}$ Kyianka). This plant form is a hexaploid $(2 n=42)$, is an erythrospermum by refers to the group of variety, the type of the development - a winter, the duration of the growing season is a medium ripe.

The traits of identification: the shape of the bush is a semi-straight; the frequency of individuals with curved flag leaves - an average (3/4 with curved flag leaves); the wax plaque on its vagina and the upper internode of the straw are absent; the wax plaque on the spike and anthocyanin colour of the straw are absent. The straw is filled weakly, strong. The shape of the spike is cylindrical; it is a medium by the density and the length, its colour is a white. The awns of lower flowering glume in the spike present; the awns at the apex of the spike by the length is a long; the pubescence of the convex surface of the upper node of the straw - weak; the shoulder width of the lower spikelet glume an average; the shape of the shoulder of the lower spikelet glume is a rounded; the length of the tooth of the lower spikelet glume is a short; the shape of the tooth of the lower spikelet glume is a slightly bent; the shape of the tooth of the lower flowering glume of the first flower is a slightly bent; the pubescence of the upper surface of the lower spikelet glume is a weak or absent.

The colour of the grain is a red, it is medium by the length and the width, its size is medium. The keel of the lower flowering glume is available; the pubescence of the outer surface of the lower spikelet scales is absent. The shape of the lower flowering glume ovoid, under the spike - without zigzag, the length of the upper internode $-28.5 \mathrm{~cm}$, the spike is an awned (Figure 1 ). The plant by the height - short stemmed $(83-92 \mathrm{~cm})$.

Sviatdonivka line of the soft winter wheat was selected by individual selection of the hybrid combination $\$ 00239 x \sigma^{x}$ Donska napivkarlykova). This plant form is a hexaploid $(2 n=42)$, it is an erythrospermum by refers to the group of variety, the type of the development is a winter, the duration of the growing season - medium ripe.

The traits of identification: the shape of the bush is a semi-straight; the frequency of individuals with curved flag leaves an average ( $1 / 2$ with curved flag leaves); the wax plaque on its vagina is weakly; the wax plaque of the upper internode of the straw is absent; the wax plaque on the spike and anthocyanin colour of the straw are absent. The straw is filled weakly, strong. The shape of the spike is cylindrical, it is a medium by the density and the length, by colour is a white. The awns of lower flowering glume in the spike present; the awns at the apex of the spike by the length is a long; the pubescence of the convex surface of the upper node of the straw is a weak; the shoulder width of the lower spikelet glume is a narrow; the shape of the shoulder of the lower spikelet glume is raised up; the length of the tooth of the lower spikelet glume is a medium; the shape of the tooth of the lower spikelet glume is a medium bent; the shape of the tooth of the lower flowering glume of the first flower is apowerfully bent; the pubescence of the upper surface of the lower spikelet glume is a weak or absent.

The colour of the grain is a red, it is medium by the length and the width, its size is medium. The keel of the lower flowering glume is available; the pubescence of the outer surface of the lower spikelet scales is absent. The shape of the lower flowering glume is ovoid, the length of the upper internode $-11.4 \mathrm{~cm}$, the spike - awned (Figure 1). Sviatdonivka plants by the height are semi-dwarf. 

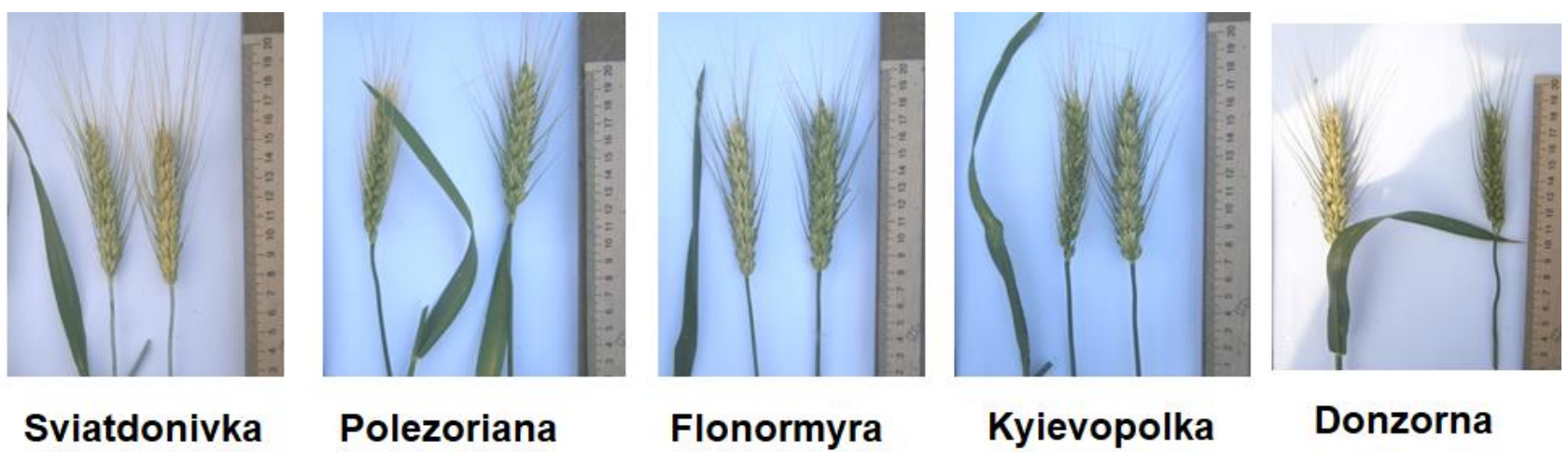

\section{Kyievopolka}

\section{Donzorna}
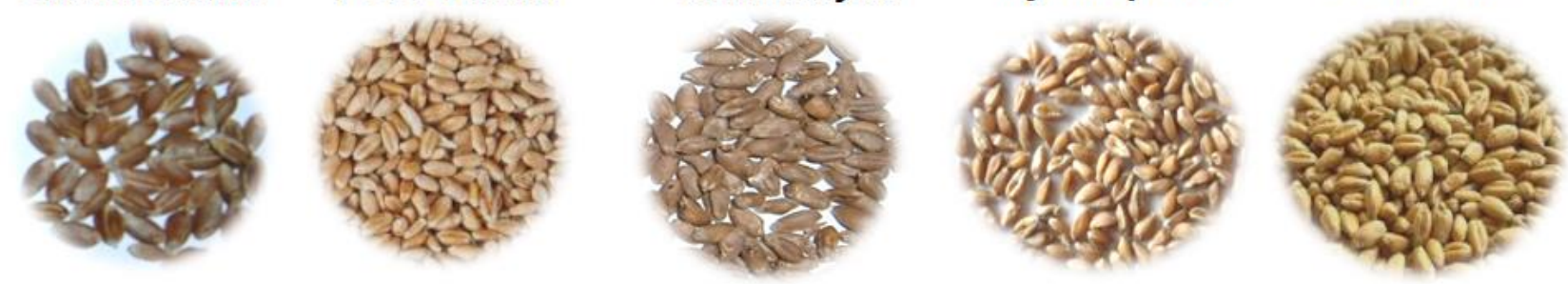

Figure 1. Plants and grains of the soft winter wheat selected lines.

Polezoriana line of the soft winter wheat was selected by individual selection of the hybrid combination 9 Zoriana Nosivska $\mathrm{x} \sigma$ Poliska 29. This plant form is a hexaploid $(2 n=42)$, it is an erythrospermum by refers to the group of variety, the maturity is a medium early, the type of the development is a winter, the duration of the growing season is a medium ripe.

The traits of identification: the shape of the bush in is a semi-upright; the frequency of individuals with curved flag leaves - high (3/4 with curved flag leaves); the wax plaque on its vagina and the upper internode of the straw are absent; the wax plaque on the spike and anthocyanin colour of the straw are absent. The straw is filled weakly, strong, thickened. The shape of the spike is cylindrical, it is a medium by the density, by the length is a long $(>10 \mathrm{~cm})$, its colour is a white. The awns of lower flowering glume in the spike present; the awns at the apex of the spike by the length is a long; the pubescence of the convex surface of the upper node of the straw is a weak; the shoulder width of the lower spikelet glume is an average; the shape of the shoulder of the lower spikelet glume is beveled; the length of the tooth of the lower spikelet glume is short; the shape of the tooth of the lower spikelet glume is a medium bent; the shape of the tooth of the lower flowering glume of the first flower is a barely bent; the pubescence of the upper surface of the lower spikelet glume is a weak.

The colour of the grain is red, its size is a big. The keel of the lower flowering glume is available; the pubescence of the outer surface of the lower spikelet scales - absent. The shape of the lower flowering glume is an ovoid, the length of the upper internode $-16.5 \mathrm{~cm}$, the spike is an awned (Figure 1). The plant by the height is a short stemmed.

Flonormyra line of the soft winter wheat was selected by individual selection of the hybrid combination $q \mathrm{~F}_{3}$ ( $q$ Norman $\mathrm{x} \sigma^{*}$ Florida) $\mathrm{x}$ \% Myronivska 61 . This plant form is a hexaploid $(2 n=42)$, it is an erythrospermum by refers to the group of variety, the maturity is a medium early, the type of the development is a winter, the duration of the growing season is a medium ripe ( 290 days).

The traits of identification: the shape of the bush is semi-upright; the frequency of individuals with curved flag leaves is high (3/4 with curved flag leaves); the wax plaque on its vagina and the upper internode of the straw are absent; the wax plaque on the spike and anthocyanin colour of the straw are absent.

The straw is filled weakly. The shape of the spike is cylindrical, its density is a medium, the length is a medium ( $9.2 \mathrm{~cm}$ ), its colour is a white. The awns of lower flowering glume in the spike present; the awns at the apex of the spike by the length is a long; the pubescence of the convex surface of the upper node of the straw is a weak; the shoulder width of the lower spikelet glume is a narrow; the shape of the shoulder of the lower spikelet glume is sublime; the length of the tooth of the lower spikelet glume is a medium; the shape of the tooth of the lower spikelet glume is a medium bent; the shape of the tooth of the lower flowering glume of the first flower is a very bent; the pubescence of the upper surface of the lower spikelet glume is a weak or absent.

The colour of the grain is a red, its size is a big. The keel of the lower flowering glume is available; the pubescence of the outer surface of the lower spikelet scales - absent. The shape of the lower flowering glume - ovoid, the length of the upper internode $20.3 \mathrm{~cm}$, the spike is an awned (Figure 1). The plant by the height is a short stemmed. The grain and the flour biochemical composition as well as technological parameters of the dough are given in Table 4.

Donzorna line of the soft winter wheat was selected by individual selection of the hybrid combination $q$ Donska napivkarlykova $x$ o Zoriana Nosivska. This plant form is a hexaploid $(2 n=42)$, it is an erythrospermum by refers to the group of variety, the type of development is a winter, by the duration of the growing season - early ripening (277-279 days).

The traits of identification: the shape of the bush is an upright; the frequency of individuals with curved flag leaves - average (1/2 with curved flag leaves); the wax plaque on its vagina and the upper internode of the straw are absent; the wax plaque on the spike and anthocyanin colour of the straw are absent.

The straw is a filled weakly, a strong. The shape of the spike is cylindrical, it is a medium by the density, the length is a long, and the colour is a white. The awns of lower flowering glume in the spike present; the awns at the apex of the spike by the length is a long; the pubescence of the convex surface of the upper node of the straw is a weak; the shoulder width of the lower spikelet glume - average; the shape of the shoulder of the lower spikelet glume is rounded; the length of the tooth of the lower spikelet glume is short; the shape of the tooth of the lower spikelet glume is a slightly bent; the shape of the tooth of the lower flowering glume of the first flower is a medium bent; the pubescence of the upper surface of the lower spikelet glume is a weak or absent. 
The colour of the grain is a red, it is a medium by the length and the width, its size is a medium. The keel of the lower flowering glume is available; the pubescence of the outer surface of the lower spikelet scales - absent. The shape of the lower flowering glume - ovoid, under the spike legible zigzag, the length of the upper internode $-9.5 \mathrm{~cm}$, the spike is an awned (Figure 1). The plant by the height is a dwarf $(69-72 \mathrm{~cm})$.

Wheat-rye translocations are widely used by selectionists to improve the valuable economic characteristics of wheat. More than 68 different wheat translocations have been described, which carry genes for resistance to pathogens and pests (Friebe et al., 2001; Oak et al., 2017). Of these, only five are of particular economic importance, including 1BL/1RS translocation, to a lesser extent $1 \mathrm{AL} / 1 \mathrm{RS}$. The provenance $1 \mathrm{BL} / 1 \mathrm{RS}$ translocation is the soft winter wheat selected lines Riebesel 47-51, derived from rye variety Petkus (Szabo \& Kolmer, 2007; Szakács et al., 2020). The source of 1AL/1RS translocation is the Amigo wheat variety, which received it from the Argentine rye variety Insave (Kozub et al., 2018). Studies have shown that wheat varieties with $1 B L / 1 R S$ translocation contain genes that control resistance to the pathogens of brown rust (Lr26), stem rust (Sr31), yellow rust (Yr9), powdery mildew (Pm8) (Li et al., 2020; Narang et al., 2020), striped mosaic virus (Wsm), aphis (Gb). Wheat varieties that carry in the genome translocation from the $1 \mathrm{R}$ chromosome of rye, have a short stem and are characterized by higher productivity (Ordoñez \& Kolmer, 2007). However, such varieties and lines of wheat have a slightly lower quality of flour, what is connected, first, with the absence of Gli-1/Glu-3 loci important for quality, located in the eliminated short arm of the wheat chromosome 1B (Li et al., 2020), and secondly, with the presence of easily soluble in water rye proteins secalins, synthesized in the endosperm of translocation wheat varieties controlled rye Sec-1 locus, located in the terminal segment of the short arm of chromosome $1 \mathrm{R}$ of rye (Poperelia, 1989; Peros et al., 2015; Pershina et al., 2020). But its negative manifestation is partially overlapped by alleles of other loci with a positive effect on the quality of flour, in particular, loci of HMW subunits of glutenins (Oak \& Tamhankar, 2017; Qaseem et al., 2018).

According to the results of the electrophoregram of spare gliadin proteins have been found that rye 1RS translocation localized on the 1BL chromosome, among all studied samples, was detected in the Donzorna line and its hybrids (and, regardless of whether that this line was used as a paternal or maternal form). The presence of wheat-rye translocation $1 \mathrm{BL} / 1 \mathrm{RS}$ is confirmed by slightly worse biochemical and technological parameters of flour and bread of this genotype, compared to the other lines, in which this translocation is not detected (Table 4). It should be noted that according to the previously performed PCR analysis in the genome of Donzorna noted the presence of the Gld 1B3 - the typical block of decalins, its some authors (Kozub et al., 2018; Li et al., 2020) denoted as the Gl-B1l allele, which somewhat offsets the negative impact of decalins on the quality of flour.

Wheat is the prime food commodity of major part of the world's population with an annual harvest of 815 million tons in 2019 . It is a leading source of calories as well as protein both for humans and livestock (Narang et al., 2020). The limited genetic diversity at the farmers' field increases genetic vulnerability to various biotic and abiotic stresses (Khangildin \& Litvinenko, 1981; Li et al., 2020). Almost wherever wheat is grown, production is significantly constrained by one or more of the three rust diseases. These include leaf rust (Puccinia triticina Eriks); stem rust ( $P$. graminis Pers. f. sp. tritic $)$; and stripe rust $(P$. striiformis Westend f. sp. triticl) (Kolmer \& Ordoñez, 2007; Narang et al., 2020). Among the three wheat rust pathogens, leaf rust cause less damage as compared to stripe and stem rust, however, due to its recurrent global occurrence, it would be anticipated that total annual losses incurred would be greater than any other rusts. In India, stem rust and stripe rust are geographically constrained, while leaf rust is endemic across all production areas. The disease not only reduce the kernel weight but also lessen number of kernels per head (Liu et al., 2014). The frequent emergence of novel pathotypes of $P$. triticina (Pt) and switching of virulence patterns constitute the main hurdles for its management (Park et al., 2000; Narang et al., 2020).

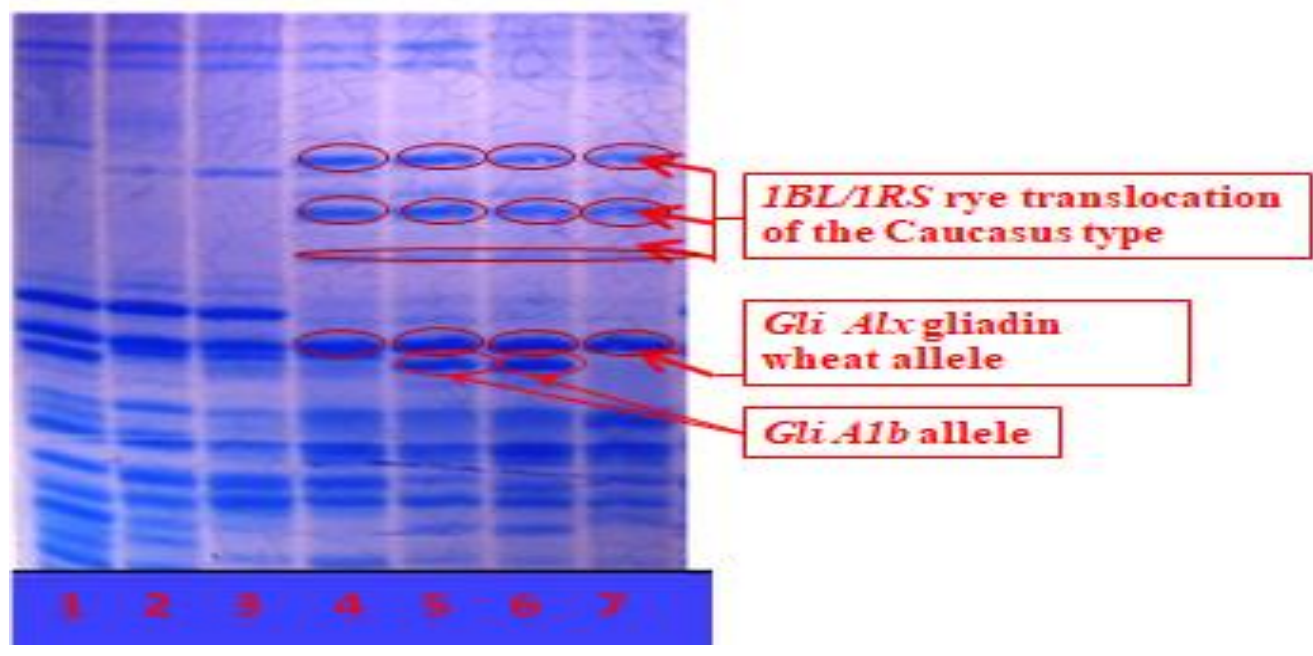

Figure 2. Electrophoregram of grain gliadins of the soft winter wheat genotypes; (electrophoresis in an acidic environment): 1 Bezosta, 2 - L 59 (UA 0107961); 3 - L 41/95 (UA 0108030); 4 - Donzorna; 5 - F ( $F_{2}$ Pekabe Rodika $\times \sigma^{7}$ Donzorna); 6 - F ( Donzorna $\times \sigma^{\pi}$ Zoriana Nosivska); $7-\mathrm{F}_{2}$ ( $\%$ Donzorna $\times$ ơ Stanychnaia); $\leftarrow$ component encoded by an the allele Gli-Alx, Gli-R1k (the block of secalines of the 'Caucasus' type).

Wild species of wheat, especially members of the tertiary gene pool, carry an immense diversity of disease resistance $(R)$ genes that could enable more sustainable disease control (Roelfs et al., 1992). Till date, 79 genes for leaf rust resistance have been designated and $\sim 44 \%$ are from wild progenitor and non-progenitor species (Szabo \& Kolmer, 2007). These genes include $L r 21, L r 22 a, L r 32$, Lr39/Lr41, Lr40, Lr42, Lr43 (A. tauschii); Lr28, Lr35, Lr36, Lr47, Lr51, Lr66 (A. speltoides); Lr63 (T. monococcum); Lr53, Lr64 (T. dicoccoides); Lr18, Lr50 (T. timopheevi); Lr37 (A. ventricosa); Lr9, Lr76 (A. umbellulata); Lr19, Lr24, Lr29 (Thinopyrum ponticum); Lr25, Lr26 (S. cereale); Lr38 (T. intermedium); Lr54 (A. kotschyi); Lr55 (E. trachycaulis); Lr56 (A. sharonensis); Lr57(A. geniculata); $\operatorname{Lr} 58$ ( $A$. triuncialis); $\operatorname{Lr} 59$ ( $A$. peregrina) and $L r 62$ from $A$. neglecta besides a number of undesignated genes (Ordoñez \& Kolmer, 2007; Liu et al., 2014; Narang et al., 2020). 
Most the lines of soft winter wheat are highly resistant to adverse biotic environmental factors, in particular to the pathogens of Fusarium head blight, the powdery mildew (9 points), the brown leaf rust, except Flonormyra, Sviatdonivka (8 points), Kyievopolka (5 points) (Figure 3).

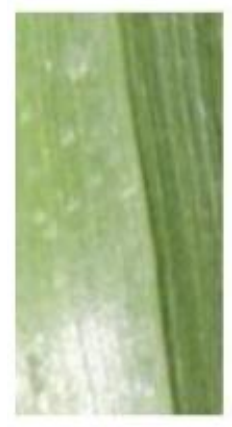

a

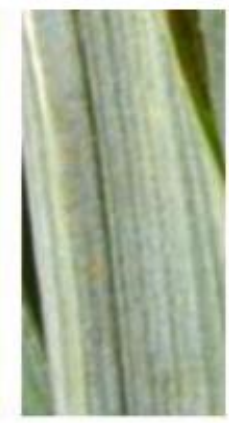

b

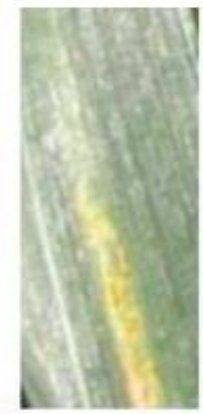

C

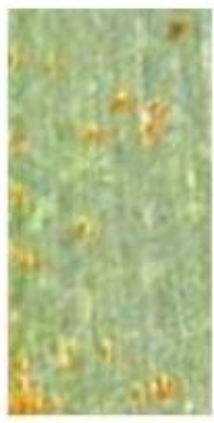

d

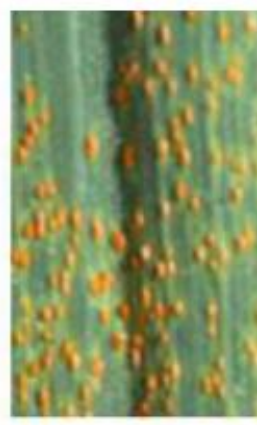

e

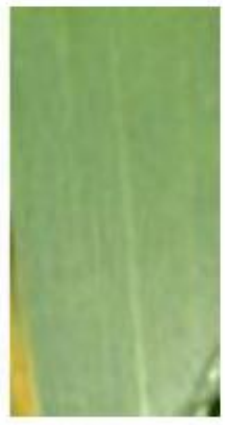

f

Figure 3. Puccinia recondita f. sp. tritici Rob. ex Desm manifestation and the area of damage plant leaves of wheat different lines and hybrids, Northern Forest-Steppe, 2019; $a$ - Donzorna (degree of damage to 1 by the Cobbs scale, or 0,4\% by the CYMMUT scale, or 9 points according to the Methods of examination of varieties (Tkachuk, 2016a); $b-\mathrm{F}_{2}$ ( $\%$ Pekabe Rodika $\times \sigma^{x}$ Donzorna) (degree of damage to 5 , or $2 \%$, or 9 points); $c-F_{2}$ (\% Donzorna $\times$ or Zoriana Nosivska) (degree of damage to 7 , or $10 \%$, or 8 points); $d-\mathrm{F}_{3}$ ( 9 Sharada $\times \sigma^{\prime}$ Donzorna) (degree of damage to 20, or 7,4\%, or 7 points); $e$ - Kyievopolka (degree of damage 40 , or above $15 \%$, or 5 points); $f-F_{2}$ ( $\%$ Donzorna $\times$ o Stanychnaia) (degree of damage 3 , or $1.5 \%$, or 9 points)

Puccinia triticina Eriks. is an obligate biotrophic rust fungus, the casual disease agent of leaf rust of wheat (Szabo \& Kolmer, 2007). Leaf rust is the most commonrust disease of wheat on a worldwide basis, occurringnearly wherever wheat is grown. Leaf rust epidemics arespread by clonally produced dikaryotic urediniospores, which can be wind dispersed for thousands of kilometres (Kolmer \& Liu, 2000). Susceptible alternate hosts of Thalictrum speciosissimum and Isopyrim fumarioides that are needed for sexual reproductionare rarely found in natural stands, thus most populationsof $P$. triticina reproduce by production of asexualurediniospores. Uredinial infections, the epidemic stage ofthe disease, occur on the leaves and leaf sheaths of wheatplants at all developmental stages (Bolton et al., 2008; Liu et al, 2014)

Leaf rust caused by Puccinia triticina is the most common and widely distributed of the three wheat rusts (Park et, 2000). Losses from leaf rust are usually less damaging than those from stem rust and stripe rust, but leaf rust causes greater annual losses due to its more frequent and widespread occurrence. Yield losses from leaf rust are mostly due to reductions in kernel weight. Many laboratories worldwide conduct leaf rust surveys and virulence analyses. Most currently important races (pathotypes) have either evolved through mutations in existing populations or migrated from other, often unknown, areas (Narang et al., 2020).

New selected plants are resistant to root rot (9 points), except - Sviatdonivka (8 points). All wheat lines have a high score to abiotic factors: frost and winter hardiness, drought resistance ( 9 points). It is also worth noting that the selection lines are resistant to lying down plants ( 9 points), slightly less stable is Flonormyra (8 points).

In addition to yield, immunity, an important indicator for selection is the quality of grain, flour and dough. A unique property of wheat flour is that its insoluble protein forms, when in contact with water, a viscoelastic protein mass known as gluten (Pakudin, 1973). Gluten, comprising roughly 78 to 85 percent of total wheat endosperm protein, is a very large complex composed mainly of polymeric (multiple polypeptide chains linked by disulphide bonds) and monomeric (single chain polypeptides) proteins known as glutenins and gliadins, respectively (Toporash, et al., 2017). Glutenins confer elasticity, while gliadins confer mainly viscous flow and extensibility to the gluten complex (Sukumaran et al., 2018). Thus, gluten is responsible for most of the viscoelastic properties of wheat flour doughs and is the main factor dictating the use of a wheat variety in bread and pasta making (Khangildin \& Litvinenko, 1981; Oak \&Tamhankar, 2017). Gluten viscoelasticity, for end-use purposes, is commonly known as flour or dough strength. Variations in grain protein content may significantly influence the dough strength properties of a wheat variety. Quantity alone, however, cannot always explain quality differences among wheat cultivars (Sukumaran et al., 2018). Therefore, protein quality, in terms of the polymeric/monomeric protein ratio and the molecular size of the protein polymer (determined by the presence of specific glutenin subunits), is also important (Ivanova et al., 2019). Wheat flour contains roughly the same amounts of glutenins and gliadins, and the unbalance of the glutenin/gliadin ratio may change its viscoelastic properties. The glutenin fraction is, however, the major protein factor responsible for variations in dough strength among wheat varieties (Pershina et al., 2020). Some authors (Pakudin, 1973; Tahmasebi et al., 2015) observe that most of the variation in dough strength parameters was explained by the amounts of soluble and insoluble glutenin.

The biochemical composition of grain and flour, as well as technological indicators of bread are given in Table 4.

Table 4. Biochemical and qualitative indicators of the grain and the flour of soft winter wheat varieties and lines (average 20182020).

\begin{tabular}{|c|c|c|c|c|c|}
\hline Variety, line & $\begin{array}{c}\text { Weight of } 1 \text { liter of } \\
\text { grain, } \mathbf{g} / \mathbf{I}\end{array}$ & $\begin{array}{l}\text { 'Raw' protein } \\
\text { content, \% }\end{array}$ & $\begin{array}{c}\text { 'Raw' } \\
\text { gluten } \\
\text { content, \% }\end{array}$ & $\begin{array}{l}\text { Volumetric bread } \\
\text { outut of } 100 \mathrm{~g} \text { of } \\
\text { drough, } \mathrm{cm}^{3}\end{array}$ & $\begin{array}{c}\text { Total baking } \\
\text { rating, points }\end{array}$ \\
\hline Smuhlianka & $849.8 \pm 2.9$ & $13.3 \pm 0.3$ & $29.6 \pm 0.3$ & $995 \pm 4.1$ & 7.7 \\
\hline Kyievopolka & $801.7 \pm 1.6^{*}$ & $13.2 \pm 0.4$ & $29.0 \pm 0.6$ & $920 \pm 3.9 *$ & $7.5^{*}$ \\
\hline Sviatdonivka & $811.0 \pm 1.9 *$ & $14.0 \pm 0.5$ & $30.5 \pm 0.2^{*}$ & $1140 \pm 7.7 *$ & $8.7 *$ \\
\hline Donzorna & $788.2 \pm 2.0^{*}$ & $13.5 \pm 0.2$ & $28.2 \pm 0.5^{*}$ & $768 \pm 4.0^{*}$ & $6.0 *$ \\
\hline Polezoriana & $755.3 \pm 2.3^{*}$ & $13.0 \pm 0.3$ & $28.1 \pm 0.6^{*}$ & $760 \pm 5.2^{*}$ & $6.3^{*}$ \\
\hline Flonormyra & $809.6 \pm 1.8^{*}$ & $12.5 \pm 0.2$ & $28.5 \pm 0.7$ & $810 \pm 3.0 *$ & $8.1^{*}$ \\
\hline
\end{tabular}

Note: * - significance $\mathrm{P}<0.05$ as compared to the control (Smuhlianka variety). 
According to the biochemical composition of the grain, the studied lines are characterized by 'raw' protein content - 12.5-14.0\%, gluten content- $28.1-30.5 \%$. The high content of gluten in the grain of the selected samples determines the nutritional value, baking properties, commodity yield of bread. By the technological indicators: the volumetric bread outut of $100 \mathrm{~g}$ of drough $768-$ $1140 \mathrm{ml}$ (Table 4). The total baking rating, points of flour wheat lines is 'quite satisfactory' have Donzorna, Polezoriana (6.0-6.3 points), 'good' - Kyievopolka, and 'excellent' - Sviatdonivka, Flonormyra (8.1-8.7 points). The bread, baked from grain Sviatdonivka and Flonormyra lines has smooth surface, light brown skin, porosity is small, thin-walled, uneven, moderate elastic, elasticity is well restored, the colour of the pulp is light with a yellow tinge (Figure 4). The taste and smell are specific to wheat bread.

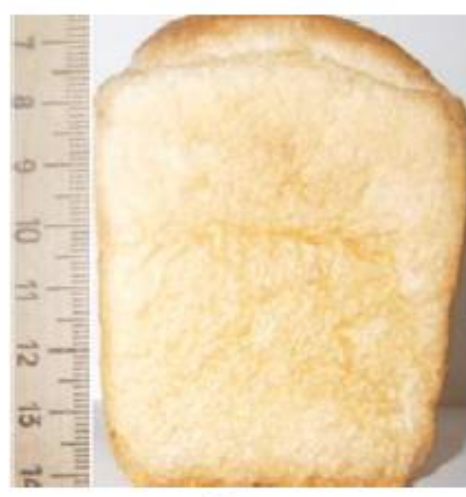

a

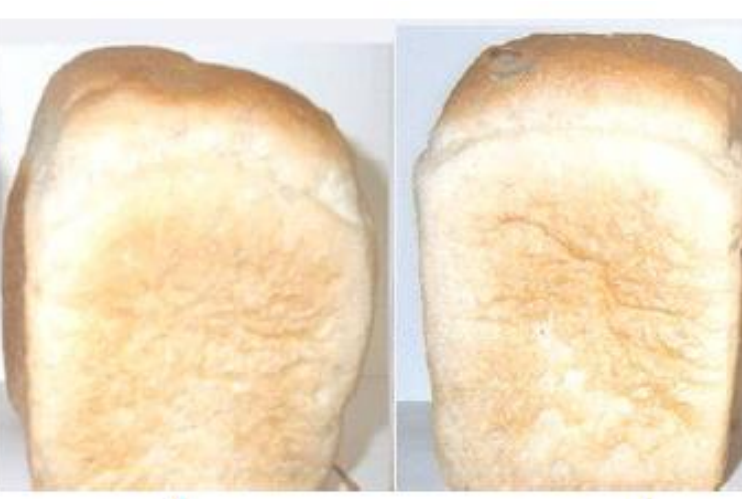

b c

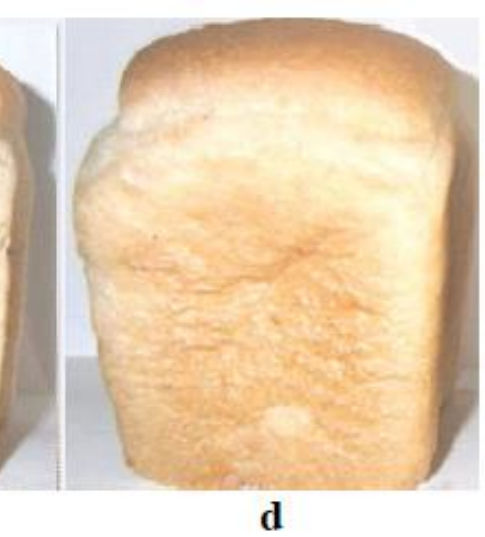

d

Figure 4. Bread from the flourt of the wheat selected lines; $a-$ Smuhlianka variety (control); $b$ - Polezoriana; c - Flonormyra; $\mathrm{d}$ Sviatdonivka.

Based on the above source material, the hybrid fund is created for perspective directions of selection, part of which is sown in Nosivska Breeding and Research Station of the NAAS nurseries, and part of which is ecological testing in the conditions of Poltava State Agrarian Academy and NSC 'Institute of Agriculture NAAS' for further study. In 2019 the new source material of soft wheat of the hexaploid level (Donzorna, Sviatdonivka, Kyievopolka, Polezoriana, Flonormyra) was transferred to the National Center for the Plant Genetic Resources of Ukraine of the V.Y. Yuryev NAAS of Ukraine, in order to register and replenishment the genetic bank of the country valuable selection material of ecologically adaptive, biological and economic characteristics.

\section{Conclusions}

In the conditions of the Northern parts of the central Forest-Steppe of Ukraine during 2005-2020 soft winter wheat promising lines (Donzorna, Sviatdonivka, Kyievopolka, Polezoriana, Flonormyra) and their hybrids were created. By means of individual selection they were studied and selected by consistently high winter and drought resistance (9-8.5 points) and productivity (average grain mass of the main spike $2.5-2.9 \mathrm{~g}$, the mass of 1000 grains $50.6-59.8 \mathrm{~g}$, the yielding capacity $5.29-6.31 \mathrm{t} / \mathrm{ha}$ ). According to the biochemical composition of the grain, the studied lines are characterized by 'raw' protein content $-12.5-14.0 \%$, gluten content 28.1-30.5\%. By the technological indicators: the volumetric bread outut of $100 \mathrm{~g}$ of drough $768-1140 \mathrm{ml}$, the total baking rating, points of flour wheat lines is 'quite satisfactory' (Polezoriana, Donzorna), 'good' (Kyievopolka), and 'excellent' (Sviatdonivka, Flonormyra).

The lines of Kyievopolka and Donzorna are the best in terms of the stability of the scale of yielding capacity variation. Kyievopolka and Donzorna lines are better by the stability of the range of variation, by the coefficient of variation (8.7-11.3\%), and variance of stability (0.21-0.51) and homeostaticity (13.1-19.2), and Donzorna, Polezoriana stood out by the selection value (5.41-5.79).

According to electrophoresis of spare proteins among the new lines of soft winter wheat, the genotype of Donzorna line has a recombinant wheat-rye translocation $1 \mathrm{BL} / 1 \mathrm{RS}$ with secalins of the 'Caucasus type', indicating the possibility of its study in selection and genetic programs on the use of spare proteins, which are controlled by Gli-Al, Gli-R1 loci as genetic markers, to identify genotypes with recombinant 1RS and determining the frequency of recombination between the shoulders 1 RS as part of various translocations within the objectives of formation recombinant inbred wheat lines with high resistance to pathogens of the stem rust and other biotic and abiotic factors.

In 2019 the new source material of soft wheat of the hexaploid level (Donzorna, Sviatdonivka, Kyievopolka, Polezoriana and Flonormyra) was transferred to the National Center for the Plant Genetic Resources of Ukraine of the V.Y. Yuryev NAAS of Ukraine, in order to register and replenishment the genetic bank of the country valuable selection material of ecologically adaptive, biological and economic characteristics.

\section{References}

Bolton, M.D., Kolmer, J.A., \& Garvin, D.F. (2008). Wheat leaf rust caused by Puccinia triticina. Molecular Plant Pathology, 9(5), 563575. Doi: 10.1007/s10681-011-0361-x

Crespo-Herrera, L.A., Garkava-Gustavsson, L., \& Ahman, I. (2017). A systematic review of rye (Secale cereale L.) as a source of resistance to pathogens and pests in wheat (Triticum aestivum L.). Hereditas, 154(14), 14-23. Doi: 10.1186/s41065-017-0033-5

Duan, X., Enjalbert, J., Vautrin, D., Solignac, C., \& Giraut, T. (2003). Isolation of 12 microsatellite loci, using an enrichment protocol, in the phytopathogenic fungus Puccinia triticina. Molecular Ecology Notes, 3, 65-67. Doi: 10.1046/j.1471-8286.2003.00350.x

Gultyaeva, E., Shaydayuk, E., Goncharov, N., Akhmetova, A., Abdullaev, K., Belousova, M., \& Kosman, E. (2016). Virulence of Puccinia triticina on Triticum and Aegilops species. Australas. Plant Pathology Journal, 45(2), 155-163. Doi: 10.1007/s13313-0160395-6

Halkett, F., Simon, J.C., \& Balloux, F. (2005). Tackling the population genetics of clonal and partially clonal organisms. Trends in Ecology \& Evolution, 20, 194-201. Doi: 10.1016/j.tree.2005.01.001

Justesen, A.F., Ridout, C.J., \& Hovmøller, M.S. (2002). The recent history of Puccinia striiformis f. sp. tritici in Denmark as revealed by disease incidence and AFLP markers. Plant Pathology Journal, 51, 13-23. Doi: 10.1046/j.0032-0862.2001.00651.x 
Eberhart, S.A., \& Russel, W.A. (1966). Stability parameters for comparing varieties. Crop Science, 6(1-2), 36-40.

Ivanova, Y.N., Solovey, L.A., Loginova, D.B., Miroshnikova, E.E., Dubovets, N.I., \& Silkova, O.G. (2019). The creation and characterization of the bread wheat line with a centric translocation t2dl.2rl. Vavilov Journal of Genetics and Breeding, 723, 846. Doi: 10.18699/VJ19.558

Khangildin, V.V., \& Litvinenko, N.A. (1981). Homeostaticity and adaptability of winter wheat varieties. Nauchno-tekhnicheskiy Biulleten VSGI, 39, 8-14.

Kolmer, J. A., \& Liu, J. Q. (2000). Virulence and molecular polymorphism in international collections of the wheat leaf rust fungus Puccinia triticina. Phytopathology, 90(4), 427-436. Doi: 10.1094/PHYTO

Kolmer, J.A., \& Ordoñez, M.E. (2007). Genetic differentiation of Puccinia triticina populations in Central Asia and the Caucasus. Phytopathology, 97, 1141-1149. Doi: 10.1094/PHYTO-97-9-1141

Kozub, N.A., Sozinov, I. A., Karelov, A.V., Bidnyk, H.Y., Demianova, N.A., Sozinova, O.I., Blume, Y.B., \& Sozinov, A.A. (2018). Studying recombination between the $1 \mathrm{RS}$ arms from the rye Petkus and Insave involved in the $1 \mathrm{BL} .1 \mathrm{RS}$ and $1 \mathrm{AL} .1 \mathrm{RS}$ translocations using storage protein loci as genetic markers. Cytology and Genetics, 52(6), 440-447. Doi: 10.3103/S0095452718060063

Li, S., Tang, H., Zhang, H., Mu, Y., Lan, X., \& Ma, J. (2020). A 1BL/1RS translocation contributing to kernel length increase in three wheat recombinant inbred line populations. Czech Journal of Genetics and Plant Breeding, 56, 43-51. https://doi.org/10.17221/79/2019-CJGPB

Liu, M., Rodrigue, N., \& Kolmer, J. (2014). Population divergence in the wheat leaf rust fungus Puccinia triticina is correlated with wheat evolution. Heredity, 112, 443-453. Doi 10.1038/hdy.2013.123

Liubych, V., Novikov, V., Polianetska, I., Usyk, S., Petrenko, V., Khomenko, S., Zorunko, V., Balabak, O., Moskalets, V., \& Moskalets, T. (2019). Improvement of the process of hydrothermal treatment and peeling of spelt wheat grain during cereal production. Eastern-European Journal of Enterprise Technologies, 3(11), 40-51. Doi: 10.15587/1729-4061.2019.170297

Meltz, G., Schlegel, R., \& Thiele, V. Genetic linkage map of rye (1992). Theoretical and Applied Genetics, 83, 33-45. https://doi.org/10.1007/BF00223842

Mitrofanova, O. P., Strelchenko, P. P., Konarev, A. V., \& Balfourier, F. (2009). Genetic differentiation of hexaploid wheat inferred from analysis of microsatellite loci. Russian Journal of Genetics, 45(11), 1351-1559. Doi 10.1134/S102279540911009X

Morgounov, A. I., Gummadov, N., Belen, S., Kaya, Y., Keser, M., \& Mursalova, J. (2014). Association of digital photo parameters and NDVI with winter wheat grain yield in variable environments Turk. Journal of Agriculture and Food Research, 38, 624-632. Doi: $10.3906 / \operatorname{tar}-1312-90$

Motsny, I. I., Blagodarova, E. M., \& Rybalka, A. I. (2017). Cytogenetic characteristics of wheat lines with modified 1RS.1BL ryewheat translocation. Cytology and Genetics, 51, 331-338. https://doi.org/10.3103/S0095452717050073

Narang, D., Kaur, S., Steuernagel, B., Ghosh, S., Bansal, U., Li, J., Zhang, P., Bhardwaj, S., Uauy, C., Wulff Brande, B., \& Chhuneja, P. (2020). Discovery and characterisation of a new leaf rust resistance gene introgressed in wheat from wild wheat Aegilops peregrina. Scientific Reports, 10, 7573. https://doi.org/10.1038/s41598-020-64166-2

Oak, M. D., \& Tamhankar, S. A. (2017). 1BL/1RS translocation in durum wheat and its effect on end use quality traits. Journal of Plant Biochemistry and Biotechnology. 26, 91-96. https://doi.org/10.1007/s13562-016-0366-6

Ordoñez, M. E., \& Kolmer, J. A. (2007). Simple sequence repeat diversity of a worldwide collection of Puccinia triticina from durum wheat. Phytopathology, 97, 574-583. Doi 10.1094/PHYTO-97-5-0574

Park, R. F., Jahoor, A., \& Felsenstein, F. G. (2000). Population structure of Puccinia recondita in Western Europe during 1995 as assessed by variability in pathogenicity and molecular markers. Phytopathology, 148, 169-179. Doi: 10.1046/j.14390434.2000.00458.x

Sukumaran, S., Reynolds, M. P., \& Sansaloni, C. (2018). Genome-wide association analyses identify qtl hotspots for yield and component traits in Durum wheat grown under yield potential, drought, and heat stress environments. Frontiers in Plant Science, 9 , 81. Doi: $10.3389 /$ fpls.2018.00081

Szabo, L. S., \& Kolmer, J. A. (2007). Development of simple sequence repeat markers for the plant pathogenic rust fungus Puccinia triticina. Molecular Ecology, 7, 708-710. Doi: 10.1111/j.1471-8286.2007.01686.x

Osterman, L. A. (2002). Metody Issledovaniya Belkov i Nukleinovykh Kislot [Methods of Study of Proteins and Nucleic Acids]. MTsNMO, Moskva (in Russian).

Pakudin, V. Z. (1973). Assessment of ecological plasticity of varieties. In: Genetic Analysis of Quantitative and Qualitative Traits Using Mathematical and Statistical Methods. VNIITEISKh, Moscow. Pp. 40-44.

Payne, P. I., \& Lawrence, G. J. (1983). Catalologue of Alleles for the Complex Gene Loci Glu-A1, Glu-B1, Glu-D1 Wich Code for HighMolecular-Weight Subunits of Glutenin in Hexaploid Weat.

Pershina, L., Trubacheeva, N., Badaeva, E., Belan, I., \& Rosseeva, L. (2020). Study of androgenic plant families of alloplasmic introgression lines (H. vulgare) - T. aestivum and the use of sister dh lines in breeding. Plants, 69, 764-766. Doi: $10.3390 /$ plants9060764

Pershina, L. A., Belova, L. I., Trubacheeva, N. V., Osadchaya, T. S., Shumny, V. K., Belan, I. A., Rosseeva, L. P., Nemchenko, V. V., \& Abakumov, S. N. (2020). Alloplasmic recombinant lines (H. vulgare) - T. aestivum with 1RS.1BL translocation: initial genotypes for production of common wheat varieties. Vavilov Journal of Genetics and Breeding, 711, 846. https://doi.org/10.18699/VJ18.393

Poperelia, F. A. (1989). Polimorfizm gliadina i ego svyaz s kachestvom. adaptivnimi svoystvami sortov myagkoy ozimoy pshenitsy [Gliadin Polymorphism and Its Relationship With Grain Quality, Productivity and Adaptive Properties of Soft Wheat Varieties]. 'Agropromizdat', Moskva, Pp. 138-150 (in Russian).

Peros, H., Dalezios, G., Liakakos, E., Delis, C., Lazaridou, T.B., \& Xyniasioannis, I. N. (2015). Molecular Detection of the 1BL.1RS Translocation in Hellenic Bread Wheat Cultivars. Cereal Research Communications, 43(2), 318-325. Doi: https://doi.org/10.1556/crc.2014.0047

Peterson, R.F., Campbell, A., \& Hannah, A. (1948). A diagrammatic scale for estimating rust intensity on leaves and stems of cereals. Canadian Journal of Research, 26(5), 496-500.

Qaseem, M.F., Qureshi, R., Muqaddasi, Q. H., Shaheen, H., Kousar, R., \& Röder, M. S. (2018). Genome-wide association mapping in bread wheat subjected to independent and combined high temperature and drought stress. PLOS ONE, 13. Doi: 10.1371/journal.pone.0199121

Ren, T., Li, Z., Yan, B., Tan, F., Tang, Z., Fu, S. Yang, M., \& Ren, Z. (2017). Targeted segment transfer from rye chromosome 2r to wheat chromosomes 2a, 2b, and 7b. Cytogenetic and Genome Research, 151, 50-59. https://doi.org/10.1159/000458743 
Roelfs, A.P., Singh, R.P., \& Saari, E. E. (1992). Rust Diseases of Wheat: Concepts and Methods of Disease Management. D. F. CIMMYT, Mexico.

Sukumaran, S., Reynolds, M. P., \& Sansaloni, C. (2018). Genome-wide association analyses identify qtl hotspots for yield and component traits in Durum wheat grown under yield potential, drought, and heat stress environments. Frontiers in Plant Science, 9 , 81. Doi: $10.3389 /$ fpls.2018.00081

Szakács, É., Szőke-Pázsi, K., \& Kalapos, B. (2020). 1RS arm of Secale cereanum 'Kriszta' confers resistance to stripe rust, improved yield components and high arabinoxylan content in wheat. Scientific Reports, 10, 1792. https://doi.org/10.1038/s41598-020-584193

Tahmasebi, S., Heidaribheidari, B., Pakniyat, H., \& Dadkhodaie, A. (2015). Consequences of 1BL/1RS translocation on agronomic and physiological traits in wheat. Cereal Research Communications, 43(4), 554-566. Doi: https://doi.org/10.1556/0806.43.2015.016 Tkachyk, S.O. (Ed.) (2016a). Metodyka provedennia ekspertyzy sortiv hrupy zernovykh, krupianykh ta zernobobovykh na prydatnist do poshyrennia v Ukraini [Methods on Examination and State Testing Plant Varieties of Cereals, Grains and Legumes for distribution in Ukraine]. UIPVE, Kyiv (in Ukrainian).

Tkachyk, S.O. (Ed.) (2016b). Metodyka vyznachennia yakosti sortiv roslyn [Methods for determining the quality of plant varieties] (2016). In Methods of Qualification Examination of Plant Varieties for Suitability for Distribution in Ukraine. Nilan-LOD, Vinnytsia (in Ukrainian).

Toporash, M.K., Motsnyy, I.I., Börner, A., Sourdille, P., \& Chebotar S.V. (2017). Polymorphism in the short arm of 1 R rye chromosomes in wheat lines with $1 \mathrm{RS} .1 \mathrm{BL}$ translocation and $1 \mathrm{R}(1 \mathrm{~B})$ substitution from different sources. Plant Varieties Studying and Protection. Doi: https://doi.org/10.7124/visnyk.utgis.16.2.1059

Weng, Y., Azhaguvel, P., Devkota, R.N., \& Rudd, J.C. (2007). PCR-based markers for detection of different sources of 1 AL.1RS and 1BL.1RS wheat-rye translocations in wheat background. Plant Breeding, 126(5), 482-486. Doi: 10.1111/j.1439-0523.2007.01331.x

\section{Citation:}

Moskalets, T.Z., Vovkohon, A.H., Ovezmyradova, O.B., Merzlova, H.V., Nevmerzhitska, O.M., Plotnytska, N.M., Gurmanchuk, O.V., Nasikovskyi, V.A., Kravets, O.O., Moskalets, V.V. (2020). Parameters of adaptability, biological and economical valuable traits of the soft wheat promising lines. Ukrainian Journal of Ecology, 10(5), 197-205. 